\title{
China's Entry Into World Trade Organization And Its Benefits For U.S. Industries
}

Ki Hee Kim, (E-mail: kimk@wpunj.edu), William Paterson University

\begin{abstract}
The November $15^{\text {th }}$ agreement imposes much more substantial concessions on China than on the U.S., which merely grants permanently what it has long granted annually. China's Concessions are the price of U.S. support for Chinese membership. Both these concessions and the WTO rules themselves should have profound impact on China, considerably opening its economy to foreign competition. WTO membership ought to compel China to change its current commercial laws and practices to conform to WTO rules. Once it is a WTO membership, China would need to negotiate trading terms on a multilateral basis with all members at once. China's concessions will benefit many major industries; among those likely to gain most are farmers, financial companies and high-tech industries. U.S. law and accounting firms are also granted expanded access under the agreement. It is widely assumed that large American corporations stand to benefit significantly from the liberalization measures that China has proposed as part of its accession to the WTO. The purpose of this research is to investigate China's entry into WTO and its benefits for U.S. industries.
\end{abstract}

\subsection{Introduction}

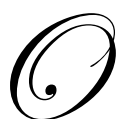

n December 11, 2001 after 15 years of arduous negotiations, China became $143^{\text {rd }}$ member of the WTO. The opening of an economy as large as China's can be disruptive to some developing countries in the short run, but in the long run, it should benefit not only China but also its trading partners. WTO membership for China is the most significant advance in relations with the U.S. since diplomatic ties were established two decades ago. WTO membership likely incline China more toward peace and progress will take time. More importantly for the U.S., joining WTO membership China will grant unprecedented access to the Chinese market for both U.S. exports and investments, including in politically sensitive sections and it will improve the chances for relations to develop peacefully on the basis of mutual interest. One important reason to welcome China into the WTO transcends mere commercial benefits. Promoting nondiscriminatory, multilateral commercial practices has been a central tenet of U.S. foreign policy since U.S. international trade policy was formulated a century ago. Also, Americans should support WTO membership for China, because it further opens the Chinese market to U.S. companies and products. This research will focus on examination of positive consequences and benefits for selected U.S. industries.

\subsection{Benefits for U.S. Retail and Wholesale Industries}

Integral to a company's success in China is the ability not just to import and export freely but the ability to control distribution and sale of its product. Foreign investors have faced restrictions in operating retail and wholesale enterprises in China. The final WTO package for China ensures that the three-year phase-in period for the liberalization of trading rights is coordinated with the liberalization of distribution and sales rights. Under the WTO terms, China allows foreign business to form wholesale joint ventures to distribute all imported and domestically produced goods beginning one year after accession, with the exception of certain goods such books and magazines,

Readers with comments or questions are encouraged to contact the author via email. 
pesticides, and oil, which will be phased in within three years after entry. Within two years of China's entry, foreign majority ownership will be permitted and all geographic and quantitative restrictions will be phased out. Also, restrictions on retailing and distribution will be eased, removing a significant competitive barrier. For example, foreign retailers such as Wal-Mart will be able to set up 100\%-owned operations and all barriers on distribution by foreign players will be phased out over three years. At present, foreign retailers can only open 50\%-owned joint ventures with central-government approval, and are limited to distributing goods made in China. Also, foreign retailers must use a Chinese company for distribution.

\subsection{Benefits for U.S. Agricultural Industries}

As WTO member, China must abide the WTO Agricultural Agreement, the aim of which is to improve market access by reducing tariffs and eliminating non-tariff barriers, limiting domestic support for agricultural production, and restricting export subsidies. It has pledged to bind all tariffs and reduce them form an average level of 31.5 percent to 17.4 percent. It will eliminate export subsidies and rapidly increase the volumes of tariff-rate quotas on most imports. In-quota tariff rates will be minimal (1-3 percent) above quota tariff for sensitive products (mostly grain) will be reduced form 80 percent to 65 percent-a level that might seem high but is moderate compared with those in the European Union and some Northeast Asian economies. Agriculture was one of the most sensitive issues in China's accession negotiations. That sensitivity was no surprise, given that some 900 million of China's 1.3 billion people live in rural areas. About 400 million people, or more than half of all employed people, are farmers. They are already slipping behind their more prosperous urban compatriots and are showing increasing signs of restiveness. Politically, the government couldn't afford to look like it was ignoring the needs of farmers in the WTO accession talks. Good news though the lower tariffs will undoubtedly be for American and other export-oriented farmers abroad, they also reflect a welcome, and potentially radical, rethinking of China's policy of agricultural selfsufficiency. China's WTO membership will require adjustments on both sides of the Pacific. Some U.S. farmers will benefit from a more open Chinese market in the years ahead and will export more agricultural commodities to China. Some U.S. agricultural producers will feel the impact of the imports of labor intensive agricultural products from China.

\subsection{Benefits for U. S. Banking Industries}

A number of foreign banks have received licenses for operations liberalized under China's WTO commitments. Foreign investment in foreign currency services was allowed upon PRC accession nationwide, and foreign or joint venture banks including Bank of Asia, Citibank, Hang Seng, HSBC, Standard Chartered, and Xiamen International Bank have received licenses. Currently foreign banks are not permitted to do local currency business with Chinese clients. China imposes severe geographic restrictions on the establishment of foreign banks.

* China has committed to full market access in five years for U.S. banks

* $\quad$ Foreign banks will be able to conduct local currency business with Chinese enterprises starting two years after accession

* Foreign banks will be able to conduct local currency business with Chinese individuals from five years after accession.

* $\quad$ Foreign banks will have the same rights as Chinese banks within designated geographic areas.

* Both geographic and customer restrictions will be removed in five years.

* Non-bank financial companies can offer auto financing upon accession.

China will permit minority foreign-owned joint ventures to engage in fund management on the same terms as Chinese firms. By three years after accession, foreign ownership of these joint ventures will be allowed to rise to 49\%. As the scope of business expands for Chinese firms, foreign joint venture securities companies will enjoy the same expansion in scope of business. In addition, 33\% foreign-owned joint ventures will be allowed to underwrite domestic equity issues and underwrite and trade in international equity and all corporate and government debt issues. 


\subsection{Benefits for U.S. Insurance Industries}

China's administrative regulations on foreign insurance Companies call for extremely high capital requirements, which foreign companies view as onerous. It also remains unclear how the requirements apply to branches, especially of firms already established in the market. In a positive development, license for life insurance operations were granted in Beijing and Tianjin more than a year ahead of WTO commitments to open these two cities. Foreign insurers will see their scope of business advanced by two years in life and non-life activities, selling the same products as their Chinese competitors. This includes health, pension and group insurance in life, and all non-life activities except for statutory insurance. Geographically, access of foreign insurers to Shenzen and Foshan has also been accelerated.

Brokers will have access to the Chinese market through cross-border and local establishment for the first time. Upon accession, they will be able to establish on a 50-50-equity basis. Foreign majority will be allowed within three years, and within five years there will be no equity restrictions. They will be able to undertake large-scale commercial risk and reinsurance business, which is the bulk of the brokerage market. Currently only two U.S. insurers have access to China's market. Under the agreement:

* China agreed to award licenses solely on the basis of prudential criteria, with non-economic needs test or quantitative limits on the number of licenses issued.

* $\quad$ China will progressively eliminate all geographic limitations within three years. Internal branching will be permitted consistent with the elimination of these restrictions.

* China will expand the scope of activities for foreign insurers to include group, health and pension lines of insurance, phased in over five years.

* China agreed to allow 50\% ownership for life insurance. Life insurers may also choose their own join venture partners.

\subsection{Benefits for U.S. R\&D Industries}

Every company with global ambitions should have China on its agenda," says J. Thomas Ratchford, distinguished professor at the National Center for Technology \& Law at George Mason University and leader of the Program of U.S.-China Cooperation in Science Policy, Research and Education. The size of its market and quantity of its human resources are enormous, especially those related o technology. Ratchford explains," Developing relationships early on with Chinese institutions-government entities, research institutes and universities, as well as companies-is important to future success." More than 30 industrial research institute member companies have established in China. These labs have varied missions and, consequently, varied reasons to consider China a strategic location for a technology presence. Conventional wisdom is to locate in China because of the lower cost of technology development.

The advantage comes first from supporting the business tactical needs in the region, namely:

* Assisting plant operations to improve quality, learn to produce new offerings, reduce costs, or increase capacity.

* $\quad$ Provide technical service and training support for local sales.

* Tailor products to the local market and culture.

* Gather and analyze technology intelligence on local and international competition.

On the strategic level, most lab managers find valued in having access to high-quality technical personnel and technology development in top-flight universities and their research institutes. There are a number of reasons for the PRC to welcome offshore R\&D establishment. They bring in; capital investment, ancillary spending, job opportunities, university and institute support, they help attract excellent foreign-trained scientists to return to their homeland. This group should begin to establish new businesses and markets thus providing some of the 90-to 300 million jobs that must be created in the decade. 


\subsection{Benefits for U.S. Telecommunication Industries}

China made important commitment to open telecom services to U.S. participation in its bilateral agreement with the United States on terms of accession. China also agreed to implement a technology-neutral policy toward the provision of telecom services, meaning that service providers-both Chinese and Foreign-can use any technology and equipment they choose to provide services. This removes a potential barrier to trade in the form of government, rather than market-determined, technology selection. Under other provisions of relevant WTO agreements, China will have to provide "national treatment" for imported telecom equipment and liberalize its investment restrictions and requirements for foreign companies that manufacture telecom equipment in China. China's telecommunications world presents a paradox: Its one of the fastest-growing sectors of the economy, yet it remains firmly under government control. A system of managed competition has made China's telecom markets one of the worlds largest and fastest - growing in just 10 years. There were long waiting lists to get new lines and, without guanxi, a new line installation took years. The growth of wireless telephone business is even more astounding. In July 2001, China surpassed the U.S. to claim the title of having more mobile subscribers than any country in the world-120.6 million at the end of the month. U.S. firms are expecting more business growth in telecom sector in China because China has agreed to implement the WTO Information Technology Agreement (ITA) upon entry into the trade body. The ITA substantially lowers customs duties on imported telecom equipment, thus making foreign products more affordable to Chinese consumers. Lower tariffs will not necessarily result in a rise in U.S exports of telecom equipment, however, as China continues to employ what the WTO calls "non-tariff barriers," including discriminatory quotas, import licensing requirement, standards testing, and domestic preferences, including "buy local policy." China has in recent years promoted this policy that discriminates against not only imported equipment but also products made by foreign-invested telecom manufactures in China.

\subsection{Benefits for U.S. E-Commerce Industries}

Recognizing the tremendous potential of the internet to boost economy activity, the Chinese Communist Party has been supporting international e-commerce. At the same time, however, the CCP is devising laws and regulations to restrict activities or information in the e-commerce channel that it sees as politically harmful or threatening to national security. While foreign ownership in local internet service providers is not allowed, this may change if China joins the World Trade Organization. Potential foreign investors would do well to understand and harness the power of guanxi (relationship networking) when it comes time to deal with legal complexities and uncertainties. Internet connections were first allowed in 1994 and the number of internet users reached 620,000. Growth since has been exponential; at the end of June 2000, there were 16.9 million internet subscribers and 27, 289 websites in China. Despite the internet's growth, the government is also attempting to devise laws and regulations to oversea its burgeoning development.

The aim is to restrict access to politically harmful information and to safeguard national security. Finally, the importance of guanxi with selected key constituencies in business and government will be implemented. It is very important for U.S. companies to cultivate this approach with different groups can help minimize legal uncertainties embedded in the current situation of Chinese e-commerce, although questions may raise about the nature and ethics of guanxi itself. Again regulations of e-commerce and other applications of the internet in China will remain a minefield for the foreseeable future.

\subsection{Foreign Direct Investments and Its Benefits}

A raft of new and amended laws have brought many areas of China's trade and investment regimes into compliance with WTO commitments and demonstrate the seriousness with which the Chinese government has approached WTO implementation efforts. China's Ministry of Trade and Economic Cooperation announced in May 2002 that more than 2, 300 laws and regulations had been amended to comply with WTO rules and 830 abolished since the country joined the world trade body on December 11, 2001. Despite progress in passing new laws, China continues to have difficulty implementing WTO terms in a number of areas. Among the problems companies hope Chinese officials will address in coming months are new areas. For example, China's regulatory regime has long been hostile to mergers-and acquisitions transactions. That regime is changing, however, both to accommodate re- 
cent developments and to further stimulate foreign investment. China's WTO accession will no doubt accelerate these changes. Nevertheless, the Chinese government will continue to have compelling political and economic reasons for maintaining controls in many economic sectors, and China's business and legal environments will continue to pose obstacles to M\&A transactions. The most obvious immediate impact of WTO entry will be continued heavy flows of foreign direct investment. China's annual average of $\$ 40$ billion in recent years dwarfs that of other developing countries and is second only to the U.S. FDI is one of the most important factors in the continued transformation of the Chinese economy. Foreign capital typically invests in more sophisticated and more profitable areas of the economy and is associated with new technologies and new work and managerial skills. WTO status reduces the risk premium that potential foreign investors attach to China by providing more policy certainty.

\section{Conclusions}

I have investigated the benefits and resulting positive impacts on selected U. S. industries after China's entry into WTO and it is recommended that in depth research on each of these U.S. industries are needed to effectively do business with Chinese companies.

\section{References}

1. The China Business Review, Jan.-Feb. 2002.

2. Supachai Panitchpakdi and Mark L. Cliford, China and the WTO, John Wiley \& Sons Ltd., 2002.

3. The CBR, July-August 2001.

4. Society for Advancement of Management, Summer 2001

5. U. S.-China Business Council, Sept. and Oct. 2001.

6. Research Technology Management, Washington, September - October 2002.

7. Ramesh Adhikari and Yongzheng Yang, Finance and Development, Washington Sept. 2002.

8. International Monetary Fund, Sept. 2002.

9. Hong Kang, Far Eastern Economic Review, Oct. 2001.

10. Journal of International Taxation, Boston; Oct. 2002. 
Notes 